\title{
أثر الظروف الإقتصادية الراهنة على الممارسات الغذائية للأسر الريفية في محافظة كفر الشيخ المبرات
}
أشرف محمد العزب(1) ، ميادة الشوادفي عوض(2) ، أموره حسن أبو طالب(2)
(1) قسم علم الاجتماع الريفي - جامعة كفر الثيخ المزيخ
(2) قسم بحوث ترشيد المر أة الريفية ـمعهد بحوث الإرشاد الزر اعي و التنمية الريفية ـ مركز البحوث الزر اعية

Received: Sep. 12,2017

Accepted: Sep. 18,2017

الملخص

استهدفت الدراسة التعرف على مستوى تنفيذ الريفيات للممارسات الذذائية الصحيحة، و الوقوف على العو امل المرتبطة و المحدة لتنفيذ تلك الممارسات في ظل الظروف الاقتصادية الراهنة بمحافظة كفر الثيخ، وقد تم تجميع البيانات اللازمة باستخدام الاستبيان بالدقابلة الثخصية من عينة من الزوجات الريفيات بلغ قوامها 355 زوجة ريفية، نم اختبار هن عشو ائياً بالاستعانة بمعادلة "كريجسي ومورجان" من قريني دقميرة، والحلافي بمركز كفر الثيخ. واستخدم لتحليل بيانات الدراسة أسلوبي الارتباط البسيط والانحدار الخطى المتعدد التدرجى الصاعد، فضلا عن استخدام التكرارات والنسب المئوية، و اختباري "ف"، و"ت"، ومعامل ثبات كرونباخ. ونم التحليل باستخدام برنامج SPSS. وتتلخص أهم نتائج الدراسة في

1- أظهرت النتائج الوصفية للدراسة أن خصائص العنصر البشرى والمتمثلة في خصائص غالبية الريفيات عينة الدراسة

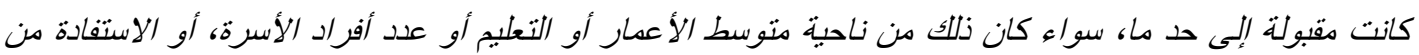

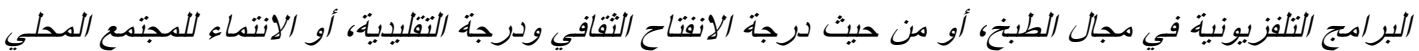
اللائي بقطن فيه، واستفادتهن من الخدمات المقدمة لهن في نطاق هذا الدجتمع. 2- أظهرت نتائج تحليل الارتباط البسيط أن تنفيذ الريفيات للممارسات الغذائية الصحيحة بمكن تحسينه بالتأكيب على الخصائص الثخصية للمبحوثة، وزوجها كالتعليج، وبالاستفادة من برامج الطبخ التي تعرض في التلبفزيون، وبزيادة درجة الانفتاح الثقافي، وبزيادة انتماء المبحوثة لمجتمعها الدحلي، وبزيادة الحبازة النزراعية للمبحوثة وأسرتها، وبزيادة استفادة المبحوثة من خذمات مجتمعها المحلي. 3- بيتت نتائج تحليل الانحدار أن تنفيذ المدارسات الغذائية الصحيحة بتحدد بتزايد استفادة الهبحوثة من خدمات مجتمعها

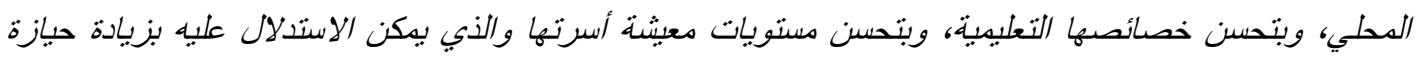
الأسرة للأجهة المنزلية، وبزيادة متوسط الدخل الثهري للأسرة، كما يتحدد تنفيذ المعارسات الغذائية الصحيحة بزيادة

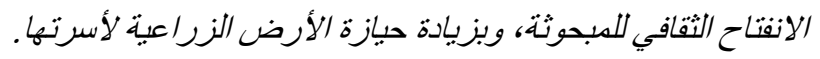

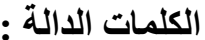

Economic conditions الظروف الإقتصادية

- المعارسات الغذائية Diety practices - الأسر الريفية Rural families

الدخل القومي، وتزداد أهمية الزراعة في الوقت الراهن بسبب الفجوة الغذائية المتزايدة خاصة الزية في محاصيل الريل الحبوب الرئيسية، حيث أن قضية تأمين الغذاء هي ألخئ أكثر

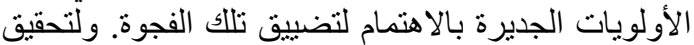

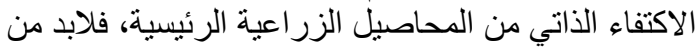
تحقيق الإنتاجية من الأرض و المياه (حجازي، 2016).
مقدمة الدراسة

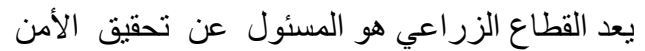
الغذائي وتلبية الاحتياجات المحلية من السلع الغذائية الئة،

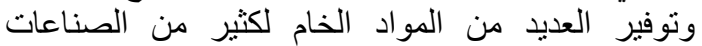
التحويلية، ويستو عب القطاع الزر اعي نحو 27.8 \% من من قوة العمل المصرية، ويساهم بنحو 17 \% من اجمالي 


\section{A. M. Alazab, et al.,}

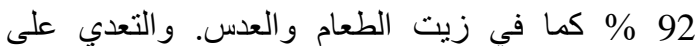

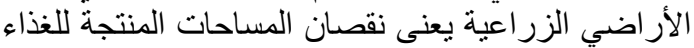

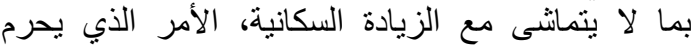
الأجيال الحالية والقادمة من أهم مبادئ حقوق الإنية الإنسان وهو لهو الحق في الطعام.

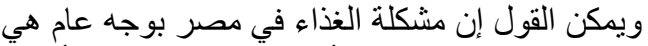

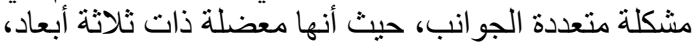

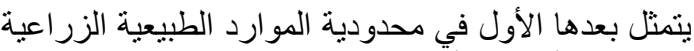

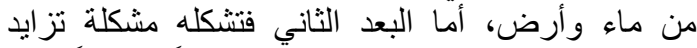

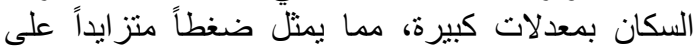

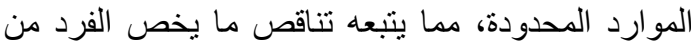

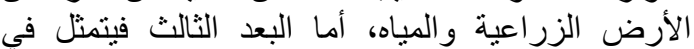

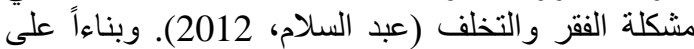
ذللك، تتز ايد نسبة واردات الغذاء، مما يترتب عليه زئب زيادة العجز في الميزان التجاري، وتهنم مصر بهربة بهذه المشكلة

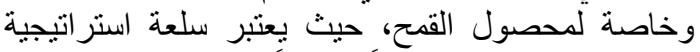

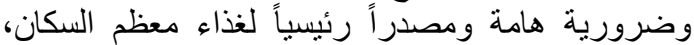

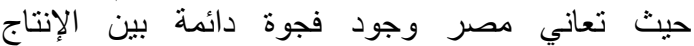

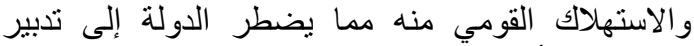

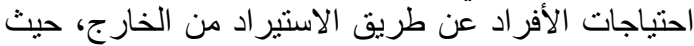
بلغت واردات مصر منه نحو 20.6 مليار جنيه عام الأن 2013

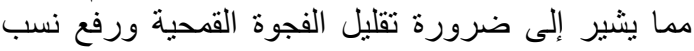
الاكتفاء الذاتي من محصول القمح (إيمان قادوس، 2015). و لا شك أن سوء التغذية يعد من أبرز تداعيات مشكلة

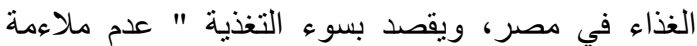

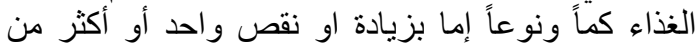

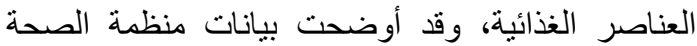

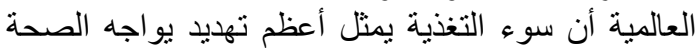

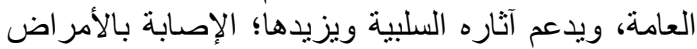

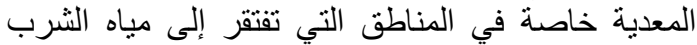

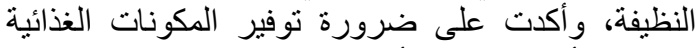

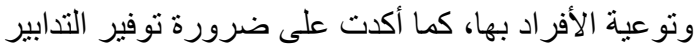

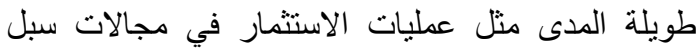

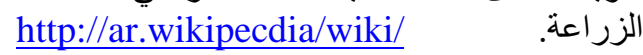

ونتير بيانات منظمة الأغذية والزر اعة للأمم المتحدة

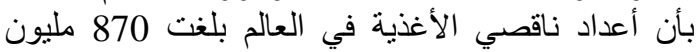

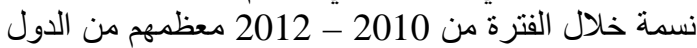
النامية، أما بالنسبة الى مصرة فلى فقد بلغت نسبة ناقصي

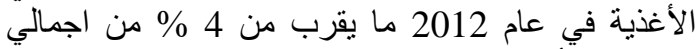

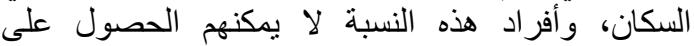

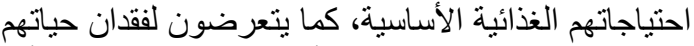
نتيجة الإصابة بسوء التغذية و الأمر اض المعائة المعدية (ابتهال أبو حسين، 2014).

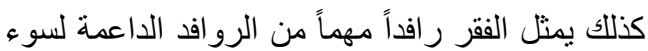

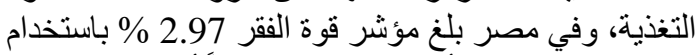

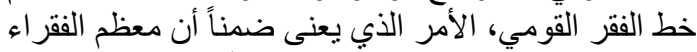

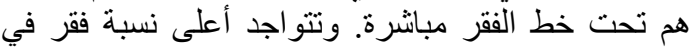
ريف الوجه القبلي 34.2 \%؛ يتبعها حضر الوجه أله القبل
ويتحقق الأمن الغذائي عندما يستطيع جميع الناس في

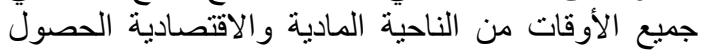

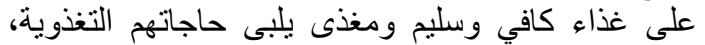
ويناسب أذواقهم الغذائية، أي أن الأمن الغذائي يقصد بـاء توفير الغذاء كماً ونوعاً مع إتاحته للجميع باستمرارية الغية

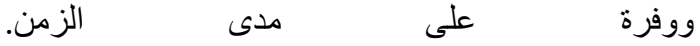
http://extension.sudansgri.net/poots/380826 وقد بينت عزة الجزار (2013) أن إمكانية الحصول

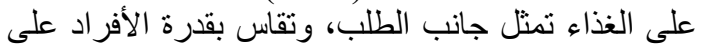

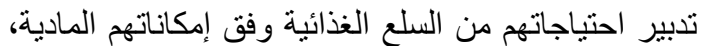

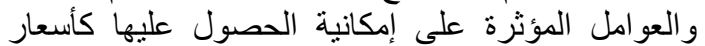

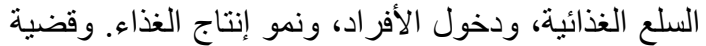
تحقيق الأمن الغذائي تعنبر من أكبر التحديات التي التئي تواجه

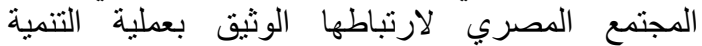

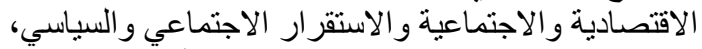

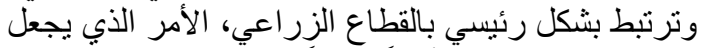

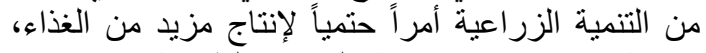

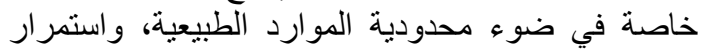

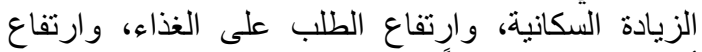

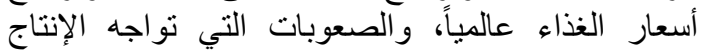
و التجارة العالمية للحاصلات الزراعية الزية الرئيسية وبخاصة الإنة الحبوب (حجازي، 2016).

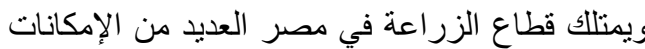
و المقومات الأرضية و والمائية و والبشرية و والرأسمالية الإنية

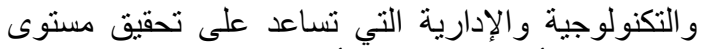

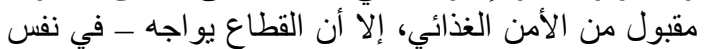

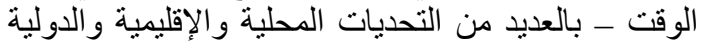

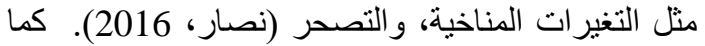

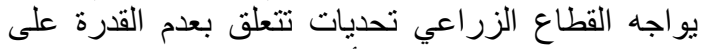

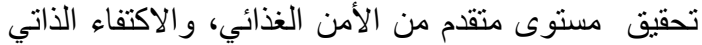

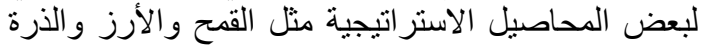

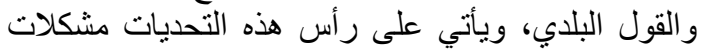

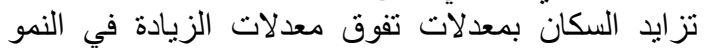

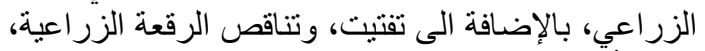

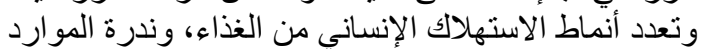

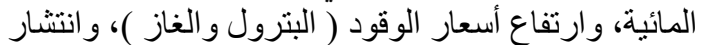
بعض الأساليب التقليدية في بعض العض مناطق التئ الإنتاج

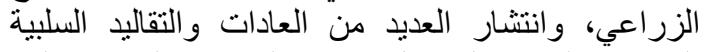

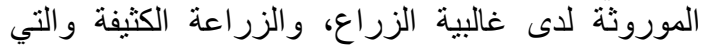

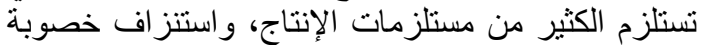

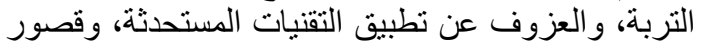

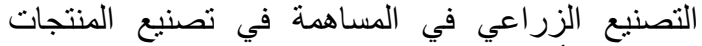
الزراعية، أو تسويث المصنع منها (هيكل، 2015 ؛ ؛ عبد

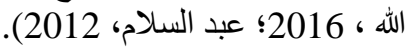

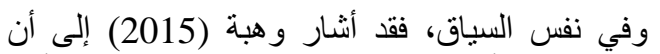

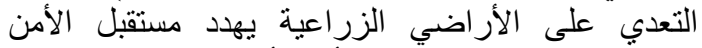

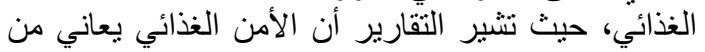

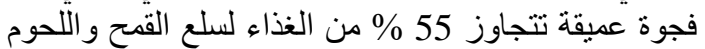

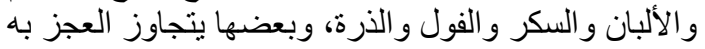


الاقتصادية تؤثر على الممارسات الغذائية ونوعية الغذاء

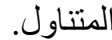

\section{مشكلة الدراسة}

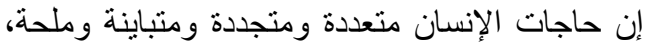

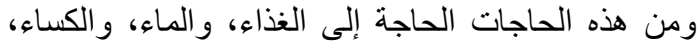

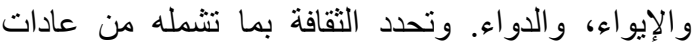

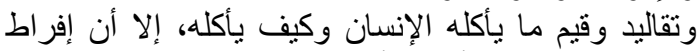

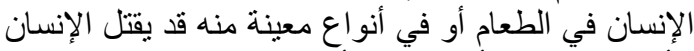

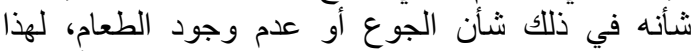

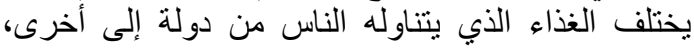

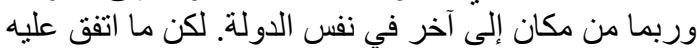

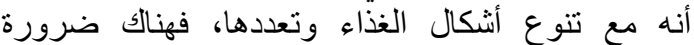
لاحتو اء الغذاء على عناصر معينة تفي باحتياجات الإنسان

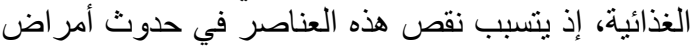

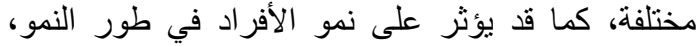

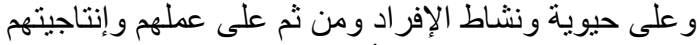

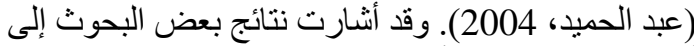

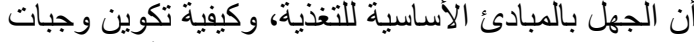

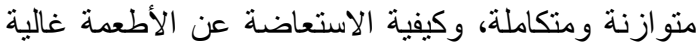

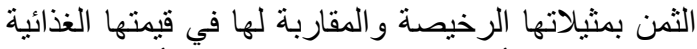

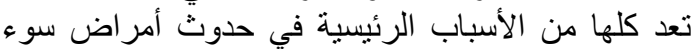

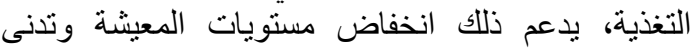

الاخول (علوي، 1986؛ و عبد المقصود، 1984)

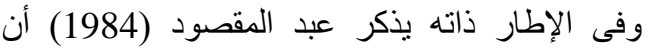

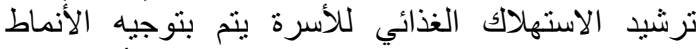
الغذائية بحيث يتسم السلؤك الغذائي للفرد و الأسرة ككل

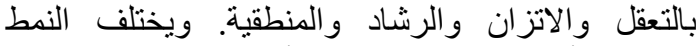

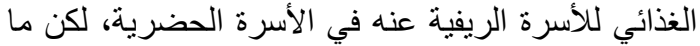

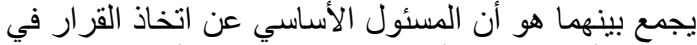

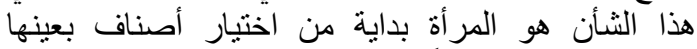

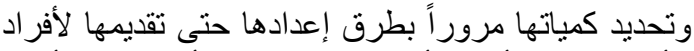

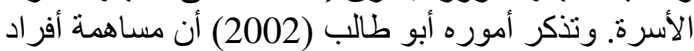
الأسرة في اتخاذ القرار ات الأسرية التتباين وفق أهمية الدور

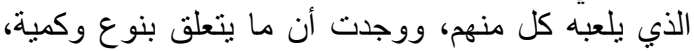

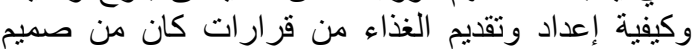

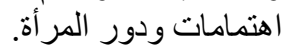

وفي ظل التغير ات الاقتصادية العالمية، وارتفاع أسعار

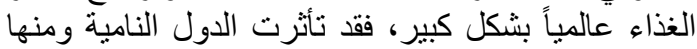

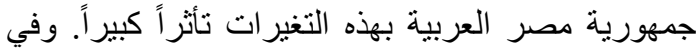

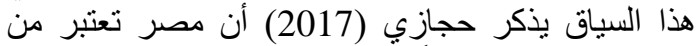
أكثر دول العالم تأثراً بالأزمة الغذائية العالمية، والتئي

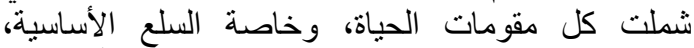
وارتفاع أسعار الغذاء و التي ارتفعت ارتفاعا شديداً في هذه التهات

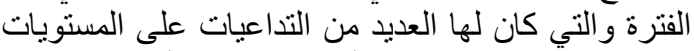
الاقتصادية و الاجتماعية والأمنية. و لا شالك أن الكية الممارسات

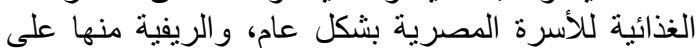

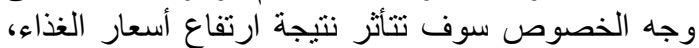

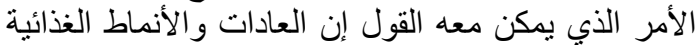
للأسر الريفية يمكن أن تتغير تبعاً لذلك.
49.3 \%)، بينما تتواجد أقل نسبة فقر في المحافظات

الحضرية 5.1 \% (و هبه، 2012).

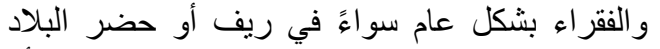

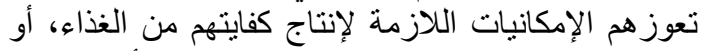

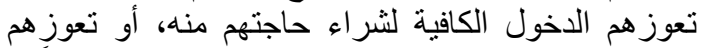

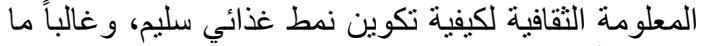

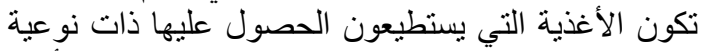
رديئة وتفقتر إلى التتوع الملائم للتغذية السليمة (أمان

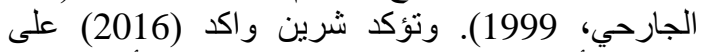

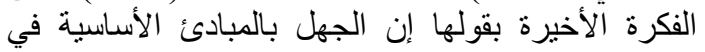

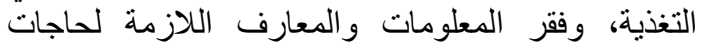

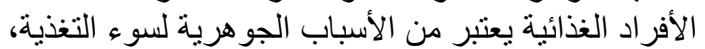
ولما يترتب عليها من أمر اض خطيرة الأباب الجره

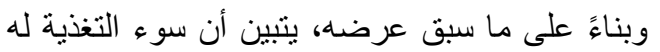

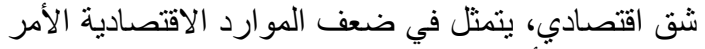

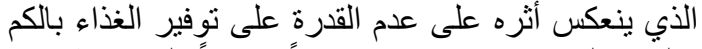

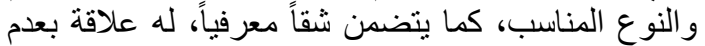

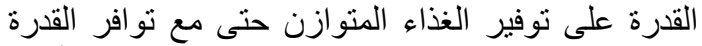

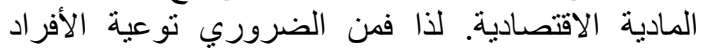
بالغذاء الصحي الذي يحتوي على جميع الكنطلبات الإنيات الغذائية

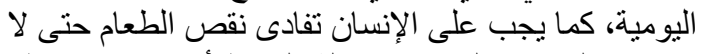

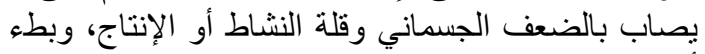

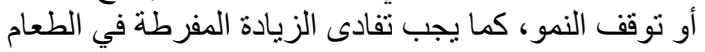

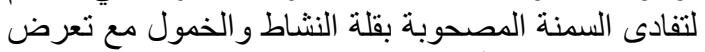
الجسم لبعض الأمراض نتيجة للبدانة وتكدس الدهون (خفاجي، 2009).

وقد بينت ليلى السباعي (دون تاريخ) أن الفرد عليه

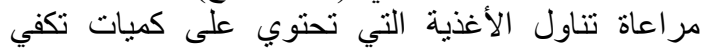

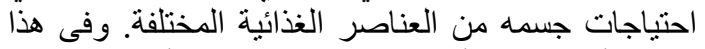

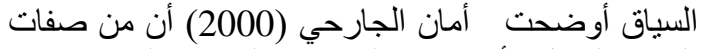

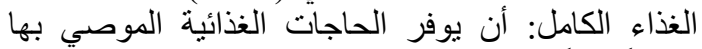

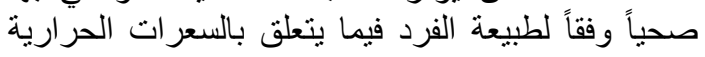
و البروتينات و العناصر المعدنية والفيتامينات.

ولا شك أن التثقيف التغذوى الذي بركز على تتمية الممارسات الغذائية السليمة التي تساعد على صلى صحة الفرد لفيد

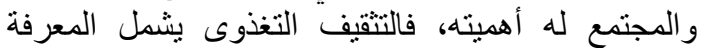

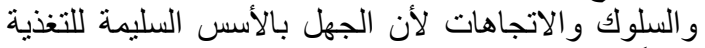

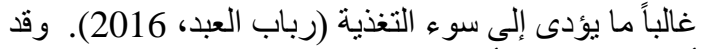

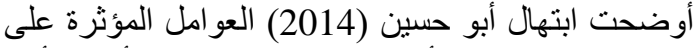

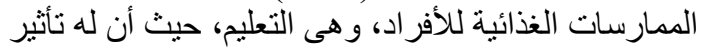
كبير في تكوين عادات الأفراد الغذائية، وذللك نتيجة التيات لاختلاف إدراكهم لأهمية الوجبة المتزنة الثنة، كما تتأثر

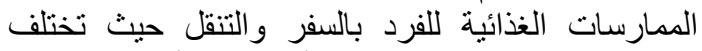

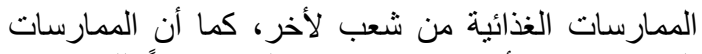

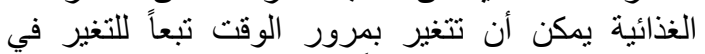
المستوى الاجتماعي، وأيضاً ثقافة الفرد نؤثر على على عمليات اختيار واستهلاك الغذاء، كما أن الممارسات الغذاندائية تنائثر بالعمر والوزن والحالة الجسمية، وأخيراً العواتئل تلثل 
2- تسهم المتغيرات الاثتى عشر سالفة الذكر إسهاماً معنوياً فريداً في تفسير جزء الاته من التباين في متغير تنفيذ

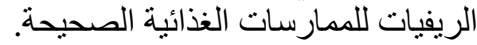

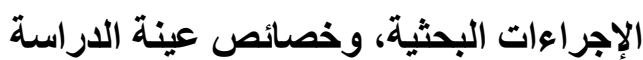
1 الإجراعات البحات البة، وخصة:

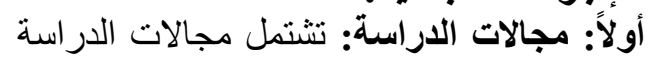

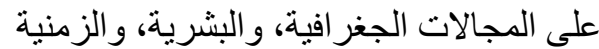

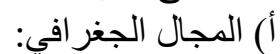

ويقصد به المنطقة التي أجريت فيها الدر اسة المبدانية، وهي محافظة كفرالثيخ، وتم اختيار مركز منها عثنة الثوائيا

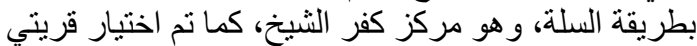

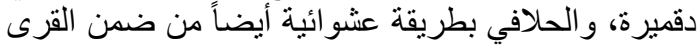

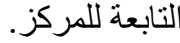

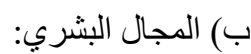
ويقصد بالمجال البشري الأفراد الثري الذين سيطبق عليهم

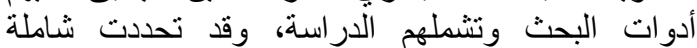

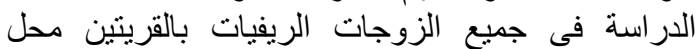

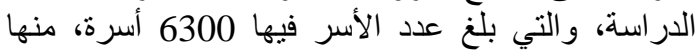
3600 أسرة بقرية دقيرة، و و 2700 أسرة بقرية الاسية الحلافي،

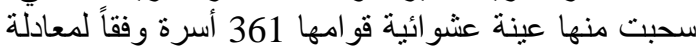
كريجسي ومورجان(Krejcie \& Morgan, 1970) وقد تم استيفاء البيانات من الزورجات الزئة الريفيات عينة

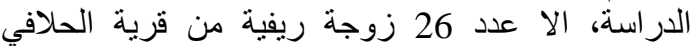

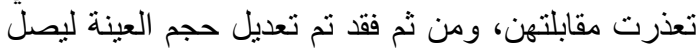

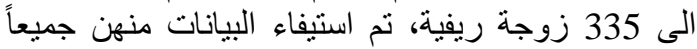

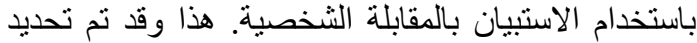

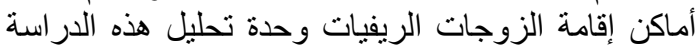

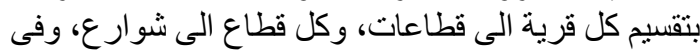

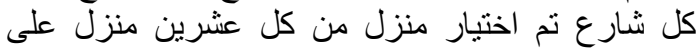

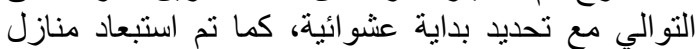

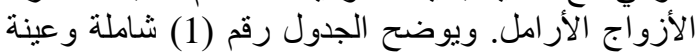
الدر استة

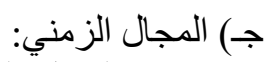

يقصد بالمجال الزمني الفترة الزئ الزمنية التي تم جمع البيانات فيها من المبحوثات حيث تم جمع البيانات الميدانية المئية

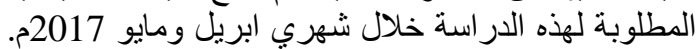
وقد استغرق استيفاء كل استمارة نحو نصف لصف ساعة في المتوسط.

ثانياً: قياس متغيرات الدراسة

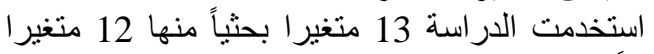
مستقلاً، ومتغير تابع واحد تم قياسها كالآتي:

أـ قياس المتغيرات المستقلة:

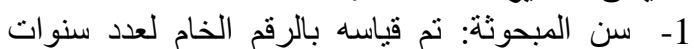

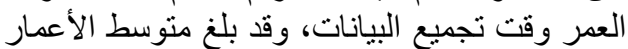

36.5 سنة، بانحر اف معياري قدره 9.7 سنة. 2- حجم أسرة المبحوثة: بانحرل وقيس بعدد أفراد الأسرة الذين يسكنون معها تحت سقف واحد، وقد بلغ منوسط عدد الخد
وتؤكد معظم البحوث الريفية التي أجريت في ميدان

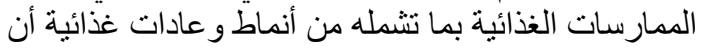

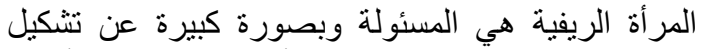

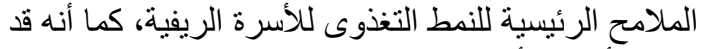

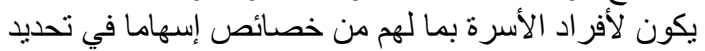

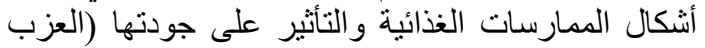

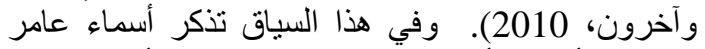

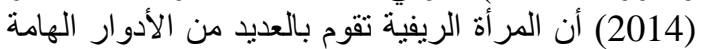

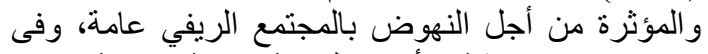

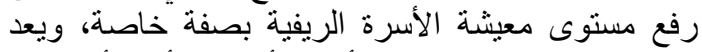

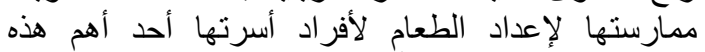

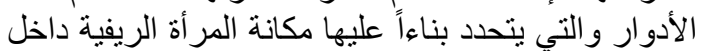

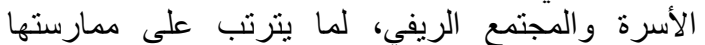
للعادات الغذائية السليمة من سلامة الأسي، لأسرة، وتحسن حالتها معاريا الصحية.

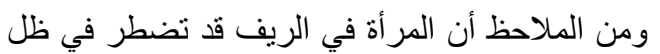
الظروف الاقتصادية الراهنة التى الاعتماد في تغذية الفية أفراد

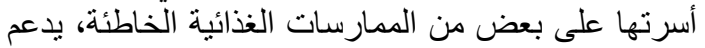

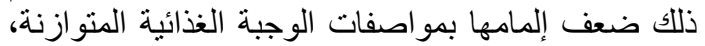

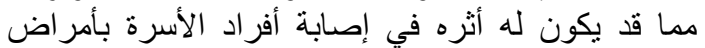

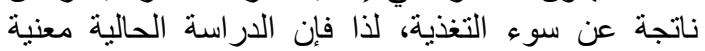

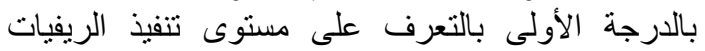

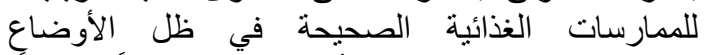

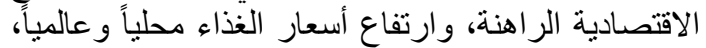
و الوقوف على أهم العوامل المرتبطة والهاع المحددة لتنفيذ هذه

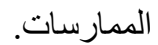
أهداف الدر اسةة تسعى الدر اسة الى تحقيق الهدفين الآتيين:

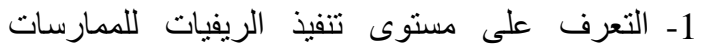
الغذائية الصحيحة بمنطقة الدر اسة.

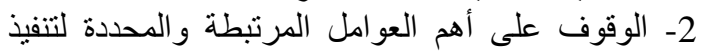

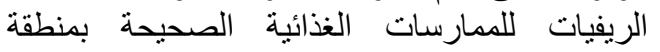
الار اسة.

\section{الفروض البحثية للاراسة:}

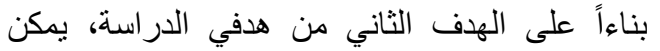

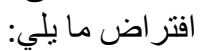
1- نوجد علاقة ارتباطيه معنوية بين درجات متغير تتفيذ

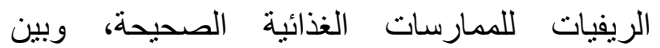

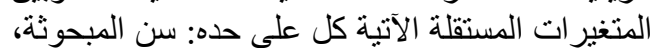

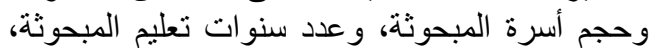

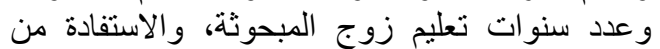

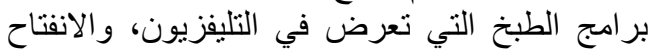
الثقافي للمبحوثة، وتقليدية المبحوثة، وانية وانتماء المبحوثية

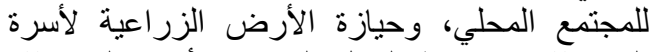

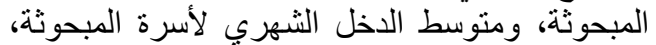

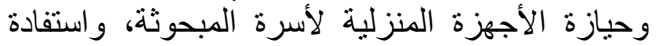
المبحوثة من خدمات المجنمع المحلي. 
مصروف البيت، وبرنامج الست غالية بيساعدني أتجاوز مشكلات ارتفاع أسعار الغذاء، وبشوف بادئ برنامج على أد الإيد عشان بقدر أشتري مكونات أثلات الطعام التي

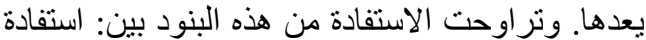

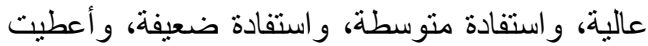

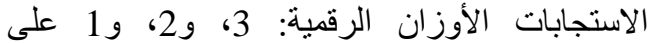

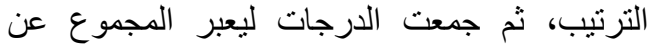

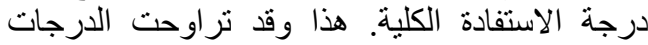
الفعلية التي حصلت عليها المبحوثات عينة الدر اسة بينة 5، و15 درجة، بمتوسط حسابي بلغ 10.9 درجة، النة

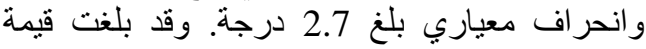

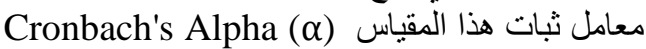

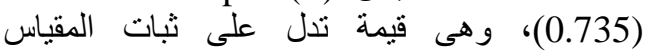
وصلاحيته لأغر اض اضى القياس.

الأفر اد في الأسرة 4.6 فرد، بانحر اف معياري قدره 1.4 فرد.

3-عدد سنوات تعليم المبحوثة: وقيس بدرجات تعادل عدد سنوات التعليم التي أتمتها المبحوثة بنة بنجاح حتى وقت تجميع البيانات، بمتوسط التئ حسابي 10.0 سنوات، و انحر اف معيار ي 6.1 سنة.

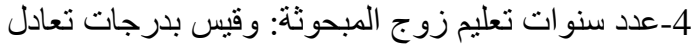

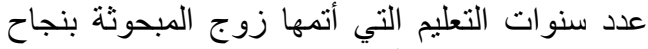
حتى وقت تجميع البيانات، بمتوسط حسابي التي 10.0 سنو ات، و وانحر اف معياري 6.4 سنة. 5-الاستفادة من برامج وانجات الطبخ التي تعرض في في التلبفزيون:

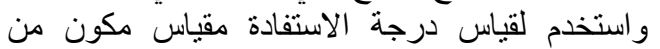

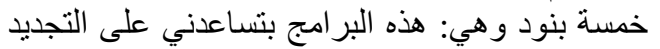

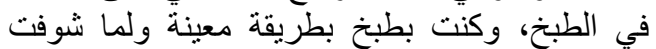

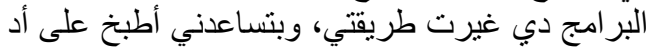

جدول رقم (1): عدد الأسر وتوزيع مفردات العينة على قرى الدراسة

\begin{tabular}{|c|c|c|c|}
\hline عينة الدر اسة & إجمالي عدد الأسر & القرية & المركز \\
\hline 179 & 3600 & دقميرة & \multirow{2}{*}{ كفر الثيخ } \\
\hline 156 & 2700 & الحلافي & \\
\hline 335 & 6300 & & \\
\hline
\end{tabular}

المصدر: مركز المعلومات ودعم اتخاذ القرار بديوان عام محافظة كفر الثيخ، عدد الأسر في قرى محافظة كفر الثيخ، بيانات غير منشورة، 2016م منركمات

هذا وقد تر اوحت الدرجات الفعلية التي حصلت عليها

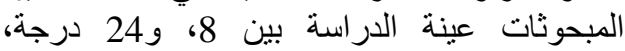

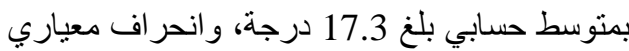

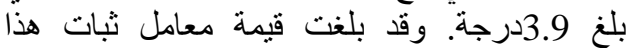

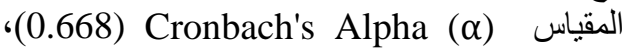
وهى قيمة تدل على ثبات المقياس وصلاحيته لأغر اض القياس.

8- انتماء المبحوثة للمجتمع المحلي: وتم قياسه بمقياس مكون من أربعة عشر بنداً تعكس انتماء المبحوثة أمباء

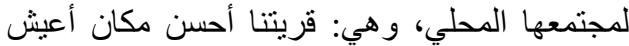

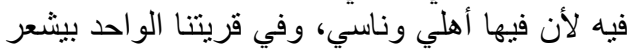

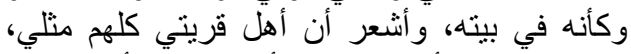

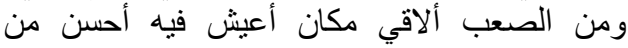

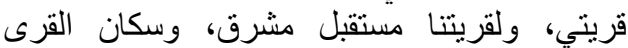

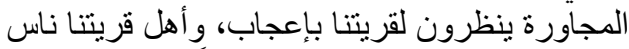

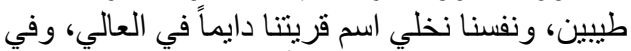

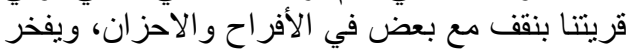

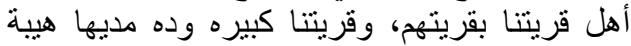

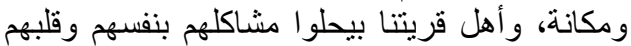

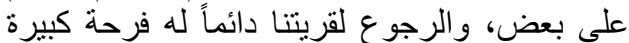

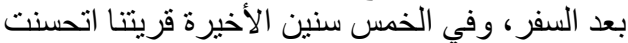

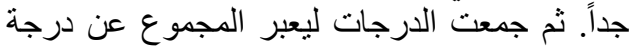

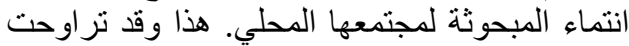

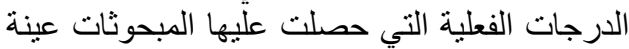

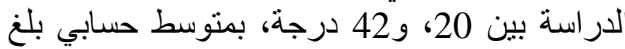
34 درجة، و انحر اف معياري بلغ 420 دردجة.
6-الانفتاح الثقافي للمبحوثة: وقيس بمقياس مكون من ستة

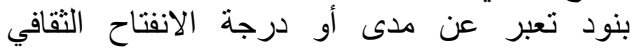

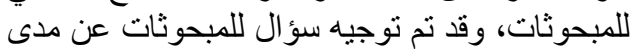

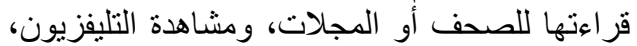

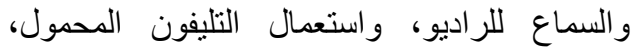

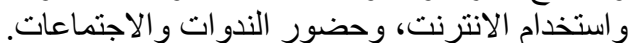

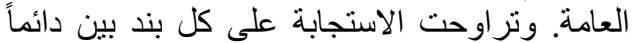

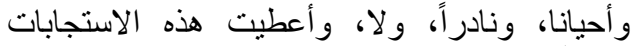
أوزاناً رقمية 3، و2، وانا، ولا، واعط، وصفر على الترنيب،

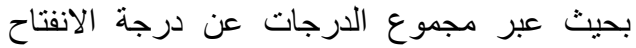

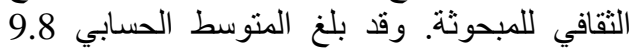
درجة بانحر اف معياري 3.0 درجة. 7- تقليدية المبحوثة: وتمر قيأسها بمقياس مكون من ثمانية

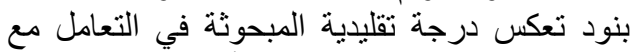

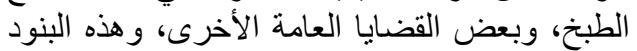
هي: طرق الطبخ اللي اتربينا عليها مفيش أحسن الطن الترن

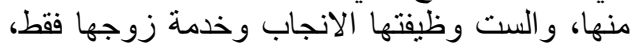

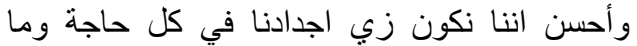

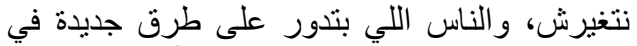

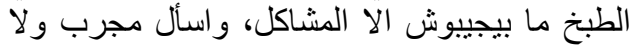

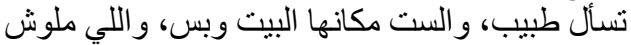

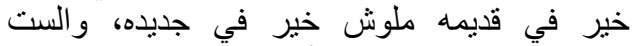

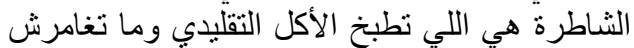

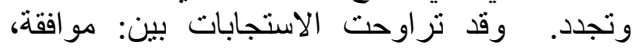

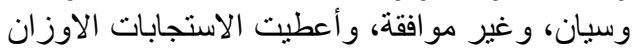

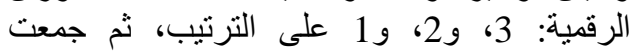
الدرجات ليعبر المجموع عن عن درجة تقليدية المبحوثة. 


\section{A. M. Alazab, et al.,}

الدراسة، حيث تم تعديل بعض الأسئلة وإعادة صباغة الإنة بعضها كما تم حذف بعض الأسئلة و إضافة البعض العضآخر.

رابعاً: الأساليب الإحصائية المستخدمة

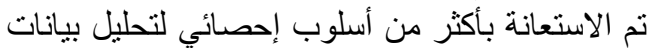

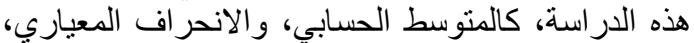

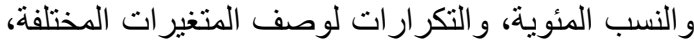

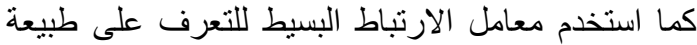

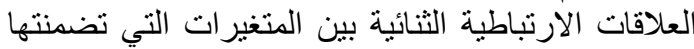

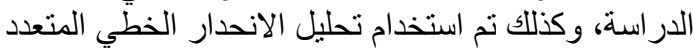

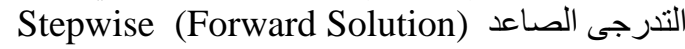
كما استخدم معامل ثبات Multiple Regression

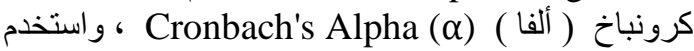

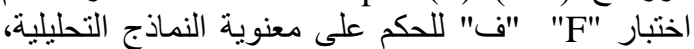

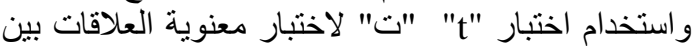
المتغيرات المستقلة والمتغير التابع في معادلات اتلات تحليل

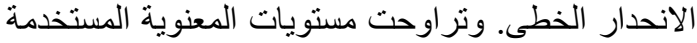

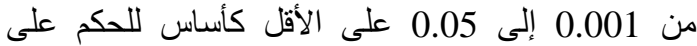
معنوية العلاقات المحسوبة، وتم التحليل باستخدام الحاسب الحاسب

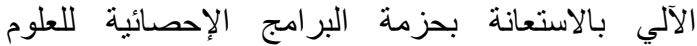

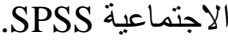

\section{2- خصائص عينة الاراسة}

أظهرت النتائج الواردة بالجدائة الجدول رقم (2) و الخاص بوصف خصائص المبحوثات الريفيات عينة الدراسة مالئا

بلي: 53 \% م من المبحوثات الريفيات يقعن فى الفئة العمرية (21- 33) سنة، بينما 30 \% م منهن يقعن فى في فئ

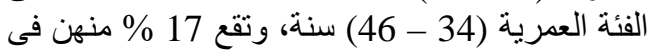
الفئة العمرية (47 سنة فأكثر ). أن 78 \% من المبحوثات الريفيات يقعن فى الفئة

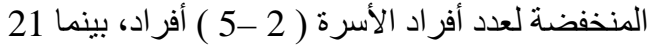

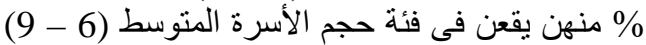
أفراد، فى حين 1 \% م منهن يقعن فى فئة حجم الأسرة المرتفع (10 أفر اد فأكثر ).

أن 38 \% من المبحوثات الريفيات أفراد عينة البحث يقعن فى فئة عدد سنوات التعليم (8 - 11 11 سنة سنة، بينما

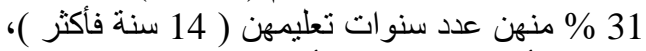
فى حين أن 23 \% منهن أميات ، بينما 8 \% \% منهن

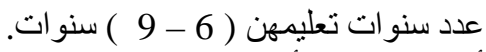
• أن 63 \% من أزواج المبحوثات الريفيات أفراد عينة

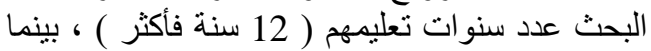

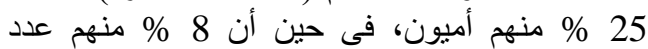

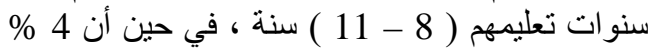

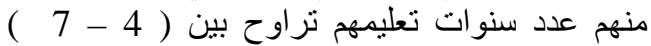

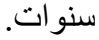
أن 54.4\% من المبحوثات كانت درجات استفادتهن

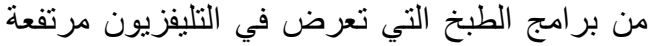

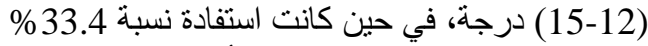
منهن متوسطة (11-9-11) درجة، أما النسبة المتنقية
9- حيازة الأرض الزراعية لأسرة المبحوثة: وقيس برقم

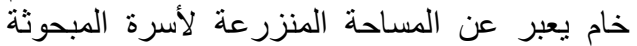

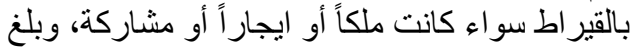

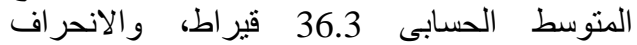
المعيارى 26.7 قير اط.

10-متوسط الدخل الثهري لأسرة المبحوثة: وقيس

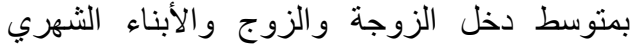

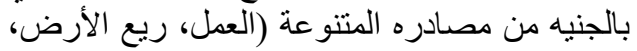

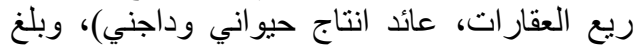
المتوسط الحسابي 2497 جنيه، بانحر اف معيارى 1692

11-حيازة الأجهزة المنزلية لأسرة المبحوثة: وقيست الأبرت

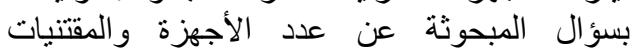
المنزلية المملوكة لأسرة المبحوثة، واتيحت المبرة الفرصة

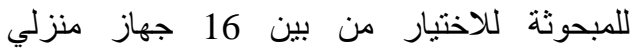
(البوتاجاز، فرن الكهرباء، الثلاجة، وسخان المياة،

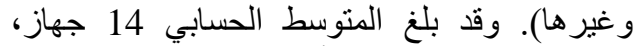

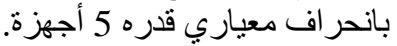
12-استفادة المبحوثة من خدمات المجتمع المحلي: وقيس بسؤال المبحوثة عن مدى استفادنها من الخدمات الخمات المتوفرة في نطاق مجتمعها المحلي، و وهي: الخدمات

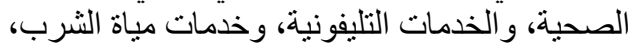

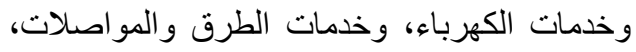
والخدمات الزراعية. وخدمات البريد، وخداء وخدمات وخلات

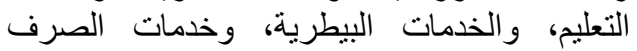
الصحي، وقد تراوحت الاستجابات على كل خدمة

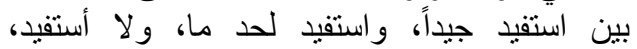
و أعطيت الاستجابات الأوزان الرقمية 3، و2، ولتئ و1

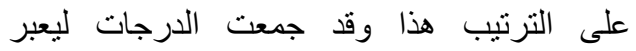

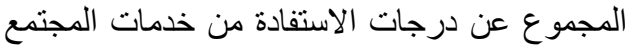

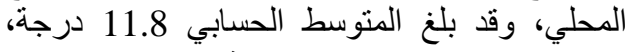
بانحر أف معياري قدره 4.6 درجة.

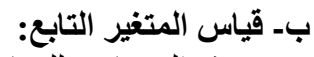

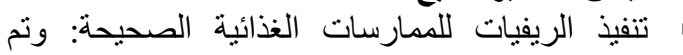

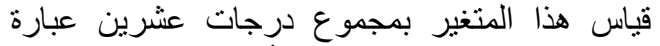

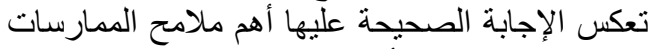

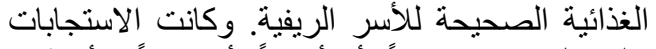

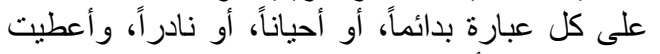

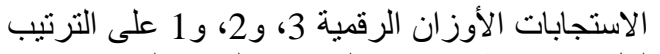

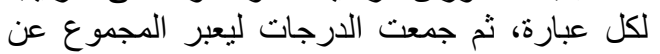

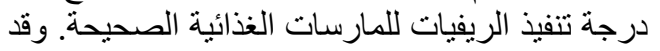

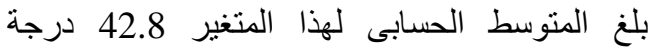

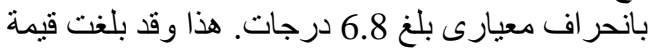

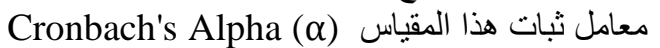
(0.790)، و هى قيمة تعكس ثبات المقياس وصلاحيته لأغر اض القياس.

ثالثاً: الاختبار المبائي لاستمارة الاستبيان:

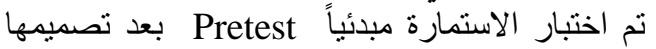
على عينة مكونة من عشرين مبحوثة من خارج قريتي 
6 \% منهن تحصل أسرهن على ( 5802 جنيه فأكثر)

• أن 81.2\%من إجمالى المبحوثات الريفيات أفراد عينة البحث حيازتهن من الأجهزة المنزلية منخفضة (16-6) جهاز، فى حين أن 17 \% م منهن الأن حيازتهن للأجهزة متوسطة (6-17-17) جهاز ، في في حين كانت

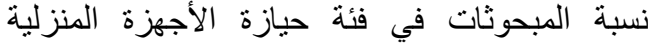

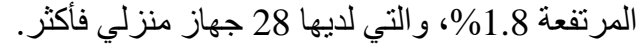

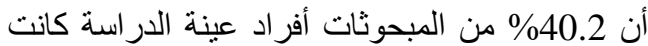

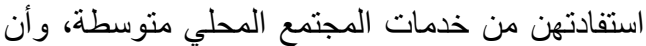

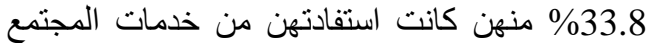

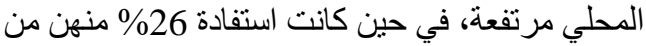
هذه الخدمات منخفضة

يتبين من استعر اض بيانات جدول رقم (2) أن غالبية

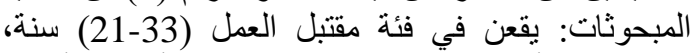
وينتمين الى أسر ذات حجم منخفض (5-13-12) أفر اد، و أتممن

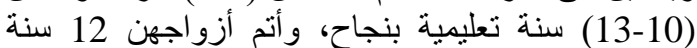

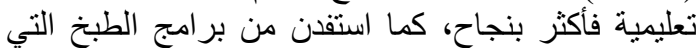

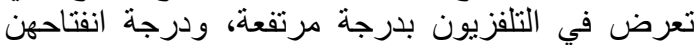
الثقافي متوسطة، ودرجة تقليدتهن متوسطة، كمنة كما كانت

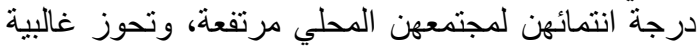

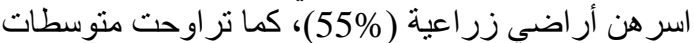
دخول أفراد أسرهن الثهرية بين 200 الى اعلى 3000 جنيه،

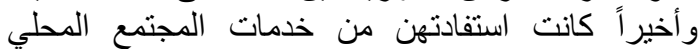
متوسطة.
21.2\% فكانت درجة استفادتهن منخفضة (5-8)

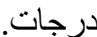

أن 46 \% من المبحوثات الريفيات أفراد عينة البحث

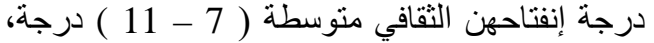
في حين أن 36 \% منهن درجة إنفتاحن النقافي مرتفعة

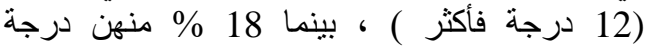

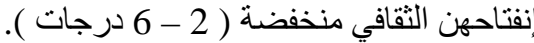
• أن 47.8\% من المبحوثات درجة تقليديتهن متوسطة )

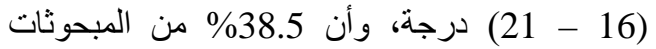
درجة تقليديتهن منخفضة (15-10) درجة، ونة وكانت درجة تقليدية النسبة المتبقية (13.7\%) درنة (10) درتفعة (2227) درجة.

• أن 51 \% من المبحوثات الريفيات أفر اد عينة البحث

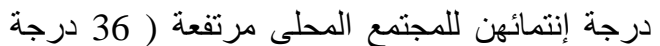
فأكثر )، في حين أن 36 \% منهن التهن كانت درجة

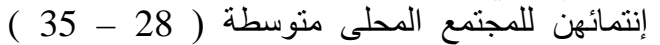
درجة، بينما 13 \% منهن درجة إنتمائهن للمجتمع المحلى منخفضة ( 20-27 درنة ) درجة. أن 45 \% من إجمالى المبحوثات الريفيات أفراد عينة

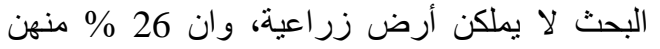

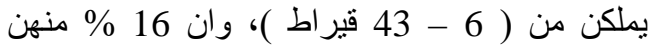

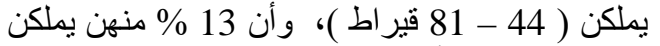

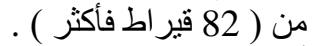
أن 81 \% من إجمالى المبحوثنات الريفيات أفراد عينة

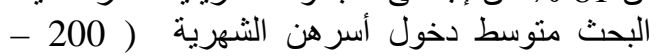
3000 جنيه) ، فئ حين أن 13 \% \% من منهن

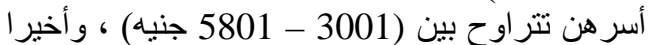
جدول رقم (2): خصائص أفراد عينة الدراسة المتغير ات المستقلة المادية

\begin{tabular}{|c|c|c|c|}
\hline$\%$ & 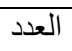 & المتغير ات المستقلة & \\
\hline & & سن المبحوثة & -1 \\
\hline 53 & 179 & (21) (33 سنة & \\
\hline 30 & 101 & (34 -34 ) سنة & \\
\hline 17 & 55 & (47 سنة فأكثر ) & \\
\hline & & حجم أسرة المبحوثة & -2 \\
\hline 78 & 261 & أفر اد & \\
\hline 21 & 70 & (6) فرد & \\
\hline 1 & 4 & (فر اد فأكثر (10 ) & \\
\hline & & عدد سنوات تعليم المبحوثة & -3 \\
\hline 23 & 77 & أمية & \\
\hline 8 & 28 & (6) - 6 - 9 ( & \\
\hline 38 & 127 & (10 - 13 ( 13 سنة & \\
\hline 31 & 103 & ( 14 سنة فأكثر ) & \\
\hline & & عدد سنوات تعليم زوج المبحوثة & -4 \\
\hline 25 & 84 & أمي & \\
\hline 4 & 12 & ( 4 - 7 ( & \\
\hline 8 & 26 & (11-8) سنة & \\
\hline 63 & 213 & (12 سنة فأكثر ( 12 ( & \\
\hline & & الاستفادة من برامج الطبخ التي تعرض في التليفزيون & -5 \\
\hline 21.2 & 71 & (8-5) درجات & \\
\hline 33.4 & 112 & (11-9) درجة & \\
\hline 45.4 & 152 & ) & \\
\hline
\end{tabular}


A. M. Alazab, et al.,

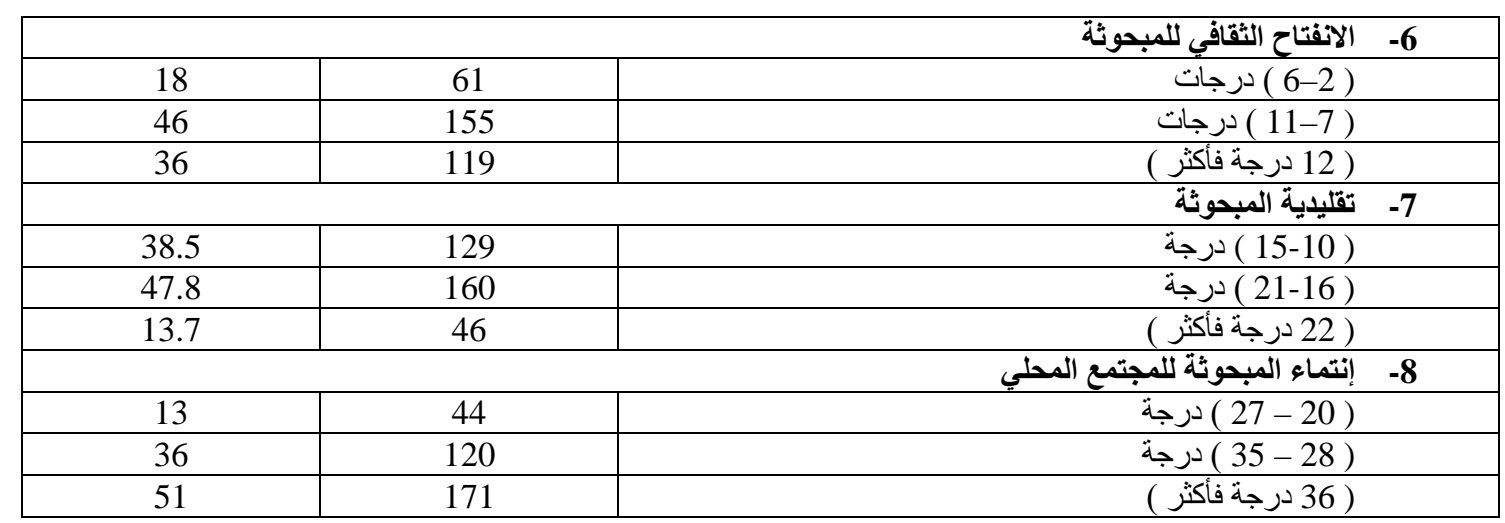

\begin{tabular}{|c|c|c|}
\hline$\%$ & 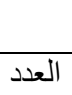 & تابع جدول رقم (2): خصائص أفراد عينة الدراسة \\
\hline \multicolumn{3}{|r|}{ حيازة الأرض الزراعية لأسرة المبحوثة } \\
\hline 45 & 150 & لا توجد حيازة \\
\hline 26 & 87 & ( 43 - 6 (ير ) \\
\hline 16 & 53 & ( 84 - 84 قير اط ) \\
\hline 13 & 43 & ( 82 قير اط فأكثر ) \\
\hline & & 10- متوسط الاخل الثهري لأسرة المبحوثة \\
\hline 81 & 273 & $(200)$ \\
\hline 13 & 43 & (3001 ( 5801 - \\
\hline 6 & 19 & ( 5802 جنيه فأكثر ( \\
\hline & & 11- حيازة الأجهزة المنزلية لأسرة المبحوثة \\
\hline 81.2 & 272 & جهاز \\
\hline 17.0 & 57 & ) جهاز \\
\hline 1.8 & 6 & (28 جهاز فأكثر) \\
\hline & & 12- استفادة المبحوثة من خدمات المجتمع المحلي \\
\hline 26.0 & 87 & ) \\
\hline 40.2 & 135 & (14-9) درجة \\
\hline 33.8 & 113 & (15 درجة فأكثر) \\
\hline
\end{tabular}

ثانياً: العلاقات الارتباطية ومحددات تنفيذ الريفيات

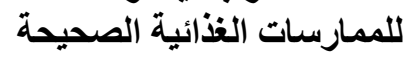

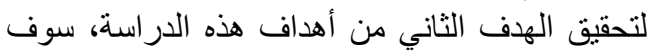

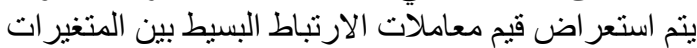

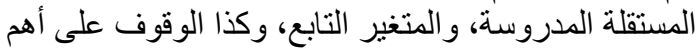

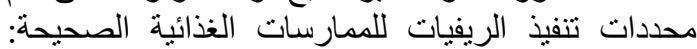
ينوقع الفرض البحثي الأول وجود علاقة إرتباطية بين كل

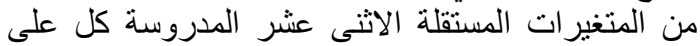

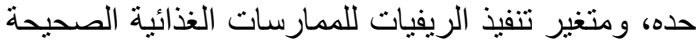

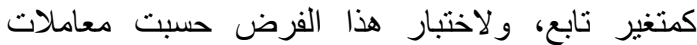

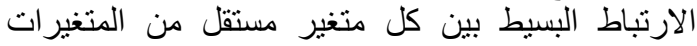

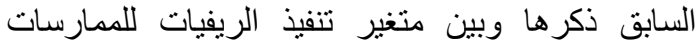

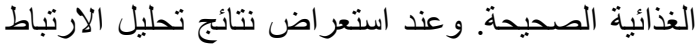

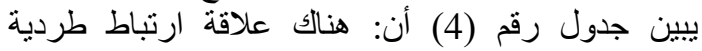

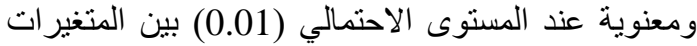
المستقلة: عدد سنوات تعليم المبحوثة، و عدد سنوات تعليم المنيخ
أنتائج الاراسة ومناقشتها أـ نتائج الاراسة اسنة

أولاً: مستوى تنفيذ الريفيات للممارسات الغذائية الصحيحة

لتحقيق الهدف الأول من أهداف الدراسة والخاص

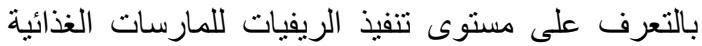

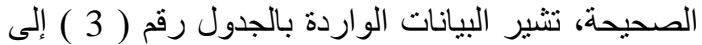
أن 69.3 \% من المبحوثات الريفيات مستوى تنفيذهن متوسط لهذه الممارسات، بينما كان 18.8 \% م كنهن كان كان مستوى تتفيذهن مرتفع لهذه الممارسات، في كئ حين كان كان 11.9 \% منهن تنفيذهن منخفض لهذه لهذه الممارسات.

ويتبين من استعر اض بيانات جدول رقم (3) أن

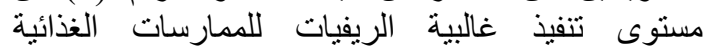

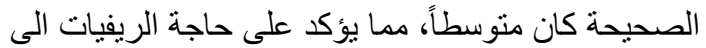

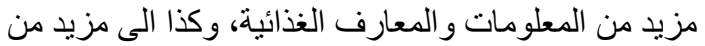
التوعية و الإرشاد لتحسين مستوى تنفيذ تلك الممارسات. 
تعرض في التلبفزيون، والانفتاح الثقافي للمبحوثة، وبين

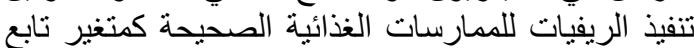

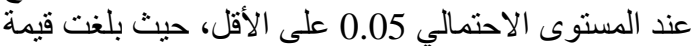

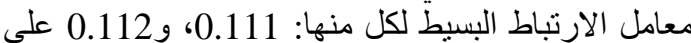
الترتيب. وتشير النتائج كذلك إلى أن قيان معاملات الإن الارتباط

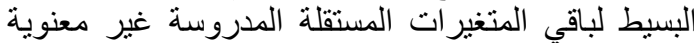

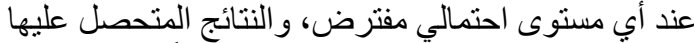
بصفة عامة تؤيد الفرض احني البحثي الأول جزئياً.

زوج المبحوثة، وتقليدية المبحوثة، وانتماء المبحوثة

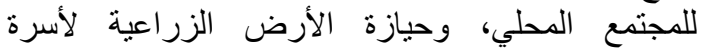
المبحوثة، واستفادة المبحوثة من خدمات المجنة الأنمع المحلي

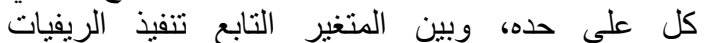
للممارسات الغذائية الصحيحة، حيث الصغيث بلغت قيم معاملات

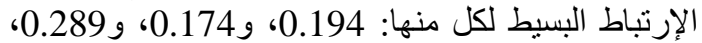
و0.229، و0.185، و0.275 على الإنى الترنيب.

بينما اتضح وجود علاقة ارتباط بسيط موجبة ومعنوية

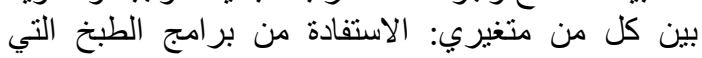

جدول رقم (3): التوزيع العددي والنسبي للريفيات حسب مستوى تنفيذهن للممارسات الغذائية الصحيحة

\begin{tabular}{|c|c|c|}
\hline$\%$ & 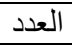 & مستوى تنفيذ الريفيات للممارسات الغذائية الصحيحة \\
\hline 11.9 & 40 & منخفض ( 24 - 35 ) درجة \\
\hline 69.3 & 232 & متوسط ( 36 - 48 ) درجة \\
\hline 18.8 & 63 & مرتفع ( 49 - 60 ) درجة \\
\hline 100 & 335 & 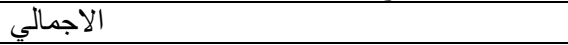 \\
\hline
\end{tabular}

جدول رقم (4): قيم معاملات الارتباط البسيط بين المتغيرات المستقلة، ومتغير تنفيذ الريفيات للممارسات الغذائية الصحيحة

\begin{tabular}{|c|c|c|}
\hline قيم ومعنوية معامل الارتباط البسيط & المتغير ات المستقلة & 3 \\
\hline 0.010 & سن المبحوثة & 1 \\
\hline 0.070 & حجم أسرة المبحوثة & 2 \\
\hline $0.194 * *$ & عدد سنوات تعليم المبحوثة & 3 \\
\hline $0.174 * *$ & عدد سنوات تعليم زوج المبحوثة & 4 \\
\hline $0.111^{*}$ & الاستفادة من بر امج الطبخ التي تعرض في التلفزيون & 5 \\
\hline $0.112^{*}$ & الانفتاح الثقافي للمبحوثة & 6 \\
\hline $0.289 * *$ & تقليدية المبحوثة & 7 \\
\hline $0.229 * *$ & انتماء المبحوثة للمجتمع المحلي & 8 \\
\hline $0.185 * *$ & حيازة الأرض الزر اعية لأسرة المبحوثة & 9 \\
\hline 0.074 & منوسط الدخل الثهري لأسرة المبحوثة & 10 \\
\hline-0.069 & حيازة الأجهزة المنزلية لأسرة المبحوثة & 11 \\
\hline $0.275^{* *}$ & استفادة المبحوثة من خدمات المجتمع المحلي & 12 \\
\hline
\end{tabular}

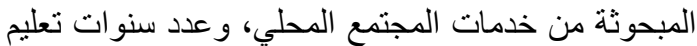

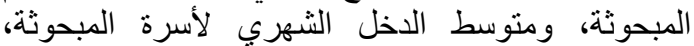

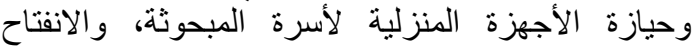

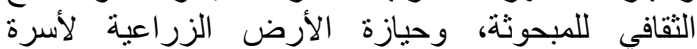

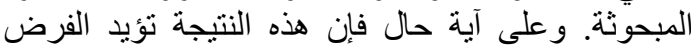
البحني الثاني جزئيا.

وتبين النتائج المتحصل عليها أن المتغيرات المستقلة

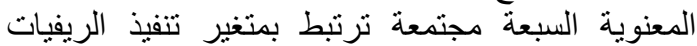

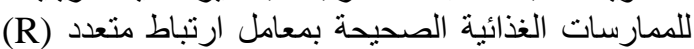
قدره 0.492 وتبلغ قيمة "فئ الفية المحسوبة لاختبار معنوية هذا المعامل 14.932 وهي قيمة قاهية معنوية إحصائيا عند

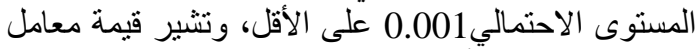
التحديد (R2) إلى أن هذه المتغير ات المستقلة السبعة تفسر نحو 24.2\% من التباين في درجات التهات تنفيذ الريفيات للممارسات الغذائية الصحيحة ، بينما ترجع النسبة المتبقية
ويتوقع الفرض البحني الثاني أن يسهم كل متغير من الندئ

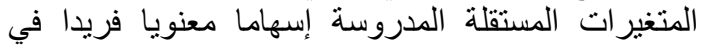
تفسير التباين في متغير تنفيذ الريفيات للممارسات الغذائية

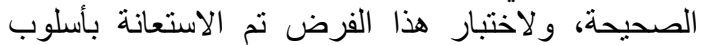

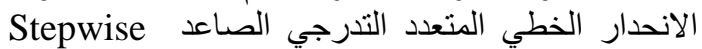
Multiple Regression (Forward Solution) للوقوف على محددات تنفيذ الريفيات للممارسات الغذائية

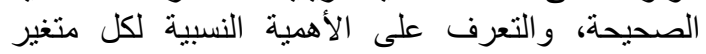

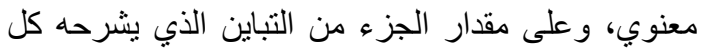

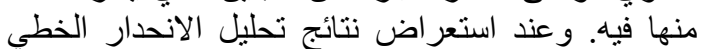

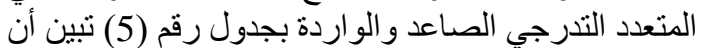
هناك سبعة متغيرات مستقلة فقط من إجمالي إثنى عثر الثر

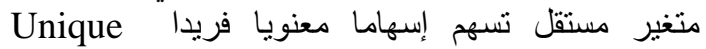
Contribution الريفيات للممارسات الغذائية الصحيحة، بعد استبعاد أثر فئر

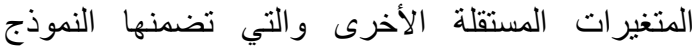
التحليلي، و هذه المتغيرات هي: تقليدية المبحوثنة، واستفادة 
A. M. Alazab, et al.,

من التباين إلى عوامل أخرى لم يتضمنها النموذج التحليلي، أو لأخطاء في القياس، أو لغير ها.

جدول (5): نتائج تحليل الانحدار الخطى المتعدد التدرجي الصـاعد بين المتغيرات المستقلة ذات الإسهام المغنوي الفريد

ومتغير تنفيذ الريفيات للممارسات الغذائية الصحيحة

\begin{tabular}{|c|c|c|c|c|c|c|c|c|}
\hline الترتبب & المسنوية & 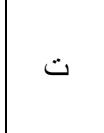 & اللتباين الكفسر فيعي التنابع & المتغر فئير التابع & $\beta$ & B & المتغير ات المستقلة & c \\
\hline 1 & 0.000 & 5.428 & 8.4 & 8.4 & 0.276 & 0.501 & تقليدية المبحوثة & $\Rightarrow 1$ \\
\hline 2 & 0.000 & 4.657 & 14.4 & 6.0 & 0.234 & 0.364 & |استفادة المبحوثة من خذمات المجتمع المحلي & 2 \\
\hline 3 & 0.000 & 4.072 & 17.9 & 3.5 & 0.210 & 0.245 & عدد سنوات تعليم المبحوثة & 3 \\
\hline 5 & 0.008 & 2.666 & 20.1 & 2.2 & 0.139 & 0.001 & متوسط الذخل الثهري لأسرة المبحوثة & 4 \\
\hline 4 & 0.002 & -3.108 & 21.5 & 1.4 & -0.167 & $|-0.244|$ & حيازة الأجهزة المنزلية لأسرة المبحوثة & 5 \\
\hline 6 & 0.007 & 2.699 & 23.2 & 1.7 & 0.136 & 0.322 & |الانفتاح الثقافي للمبحوثة & 6 \\
\hline 7 & 0.035 & 2.116 & 24.2 & 1.0 & 0.109 & 0.022 & حيازة الأرض الزر اعية لأسرة المبحوثة & 7 \\
\hline
\end{tabular}

ب-مناقشة أهم النتائج البحثية

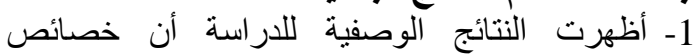

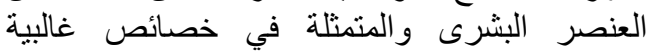

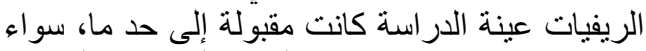

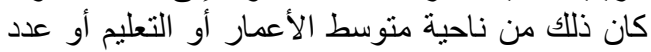

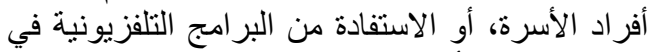

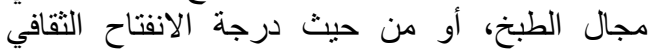
ودرجة التقليدية، أو الاتنماء للمجتمع المحلي اللائي

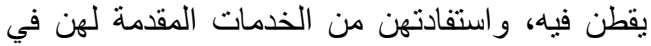
نطاق هذا المجتمع. 2- أظهرت نتائج تحليل الارتباط البسيط أن تنفيذ الريفيات

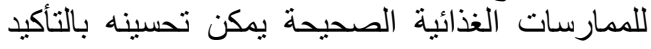

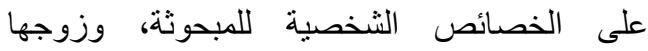
كالتعليم، وكنلك بالاستفادة من برامج الطبخ الطبح التي تعرض في التليفزيون، وبزيادة درجة الآنفادئاح الثنافي،

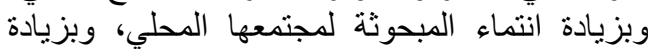

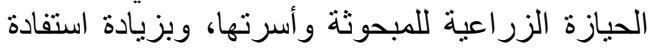
المبحوثة من خدمات مجتمعها المحلي.

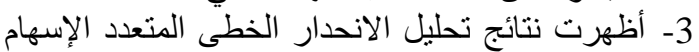

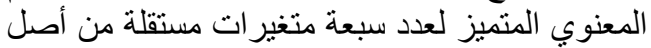

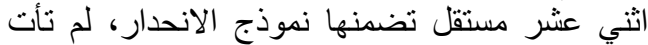

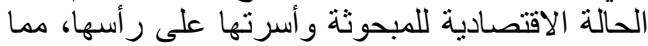

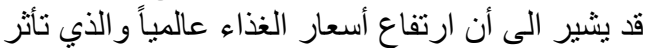

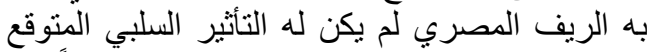
على ضعف خصائص النمط الغذائي الريفي معبراً النها لهنه

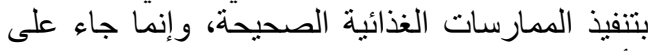

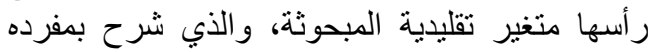

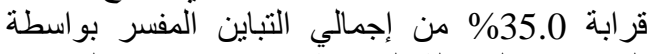
المتغيرات المستقلة المعنوية في متغير تنفيذ الريفيات المئي

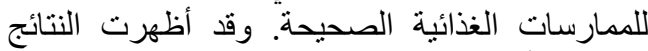
الوصفية أن 86.3\% من اجمالي الريفيات تراوحت الطت

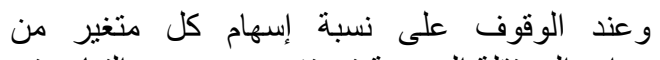
المتغير ات المستقلة المعنوية في تفسير جزء من التهام التباين في

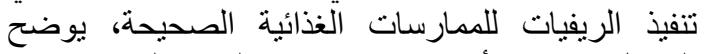
الجدول رقم (5) أن نحو 8.4\% من التباين المفير المفر يعزي

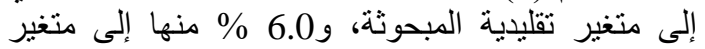

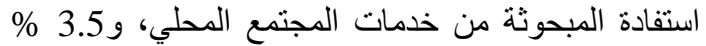

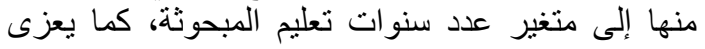

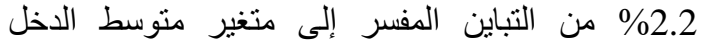

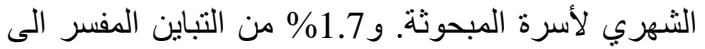

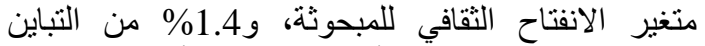

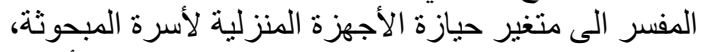

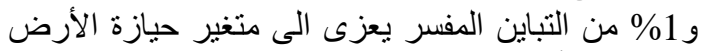

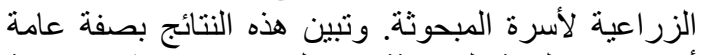

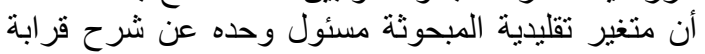

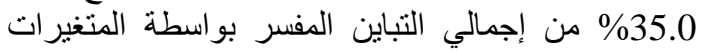
المستقلة المعنوية في متغير تنفيذ الريفيات للممارسات الغذائية الصحيحة.

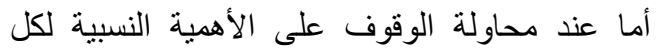

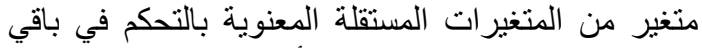

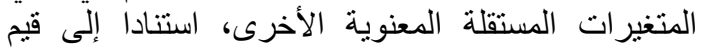

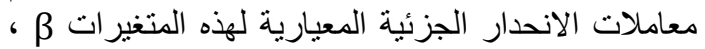

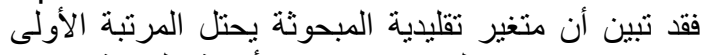
(بيتا= 0.276)، يليه من حيث الأهمية النسبية متغير الألير

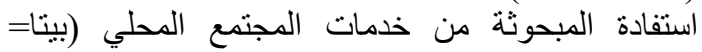

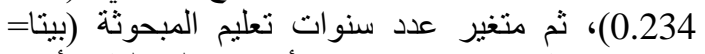

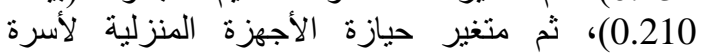

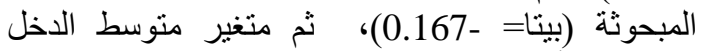

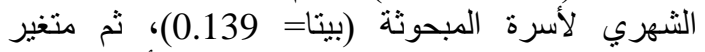

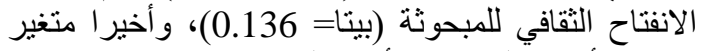

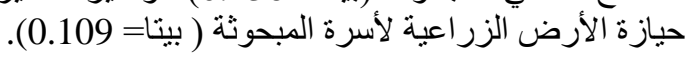


البحوث الزراعية، وزارة الزراعة و إستصلاح الأر اضى، نشرة بحثية رقم 237، الزية

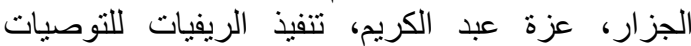

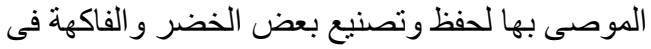

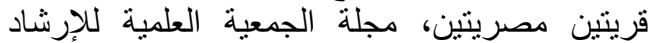

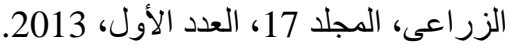

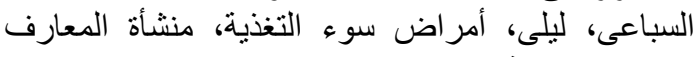

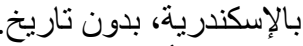

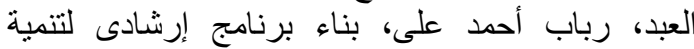

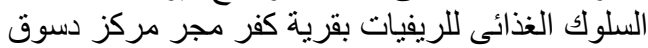

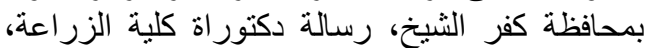

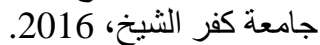
العزب، أشرف محمد، و أموره حسن أبو طالب، وميرفت

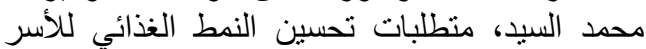

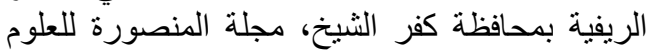

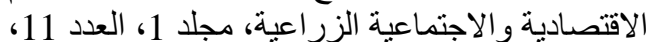

2010

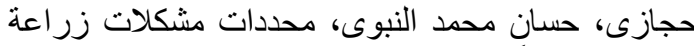

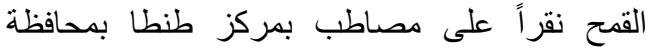

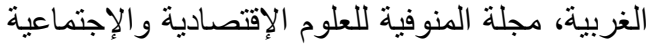
الزراعية، كلية الزراعة جامعة المنوفية، مجلد 2017، الإنة فبر اير، الز اعبة، 2017.

حجازى، حسان محمد النبوى، محددات تشكيل روابط وابط

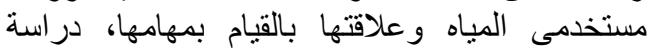

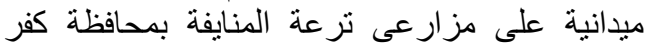

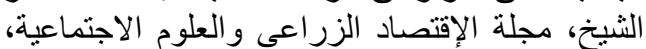

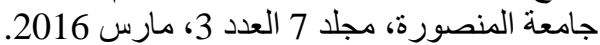
خفاجى، أحمد، التغذية الصحية والجسم السليم، دار الشرق

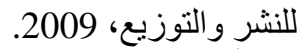

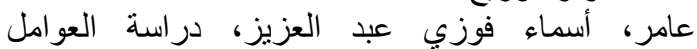

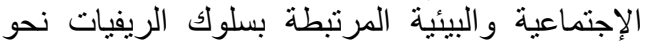

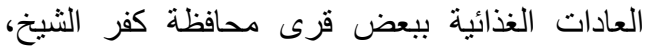

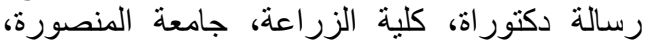

2014

عبد الحميد، عبد الحميد عجيلة، نموذج تحليلي سببي

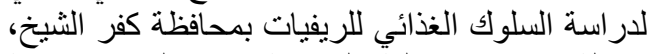

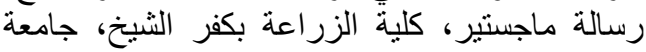
طنطا، 2004.

عبد السلام، محمد السيد، الأمن الغذائى للشعب المصرى، التهر،

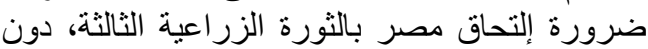
ناشر ، 2012.

عبد الله، مظهر محمد فوزي، تصور للتركيب والتكثيف

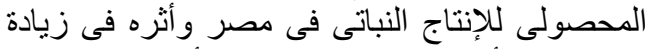

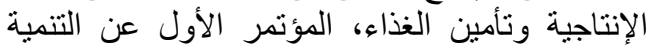

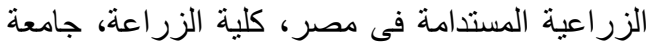

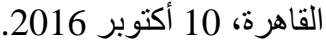

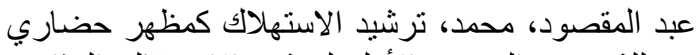

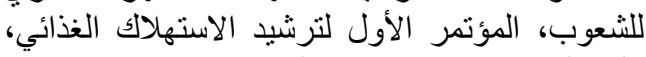
كلية الزراعة، جامعة قناة السويس، 27-29 مارس، لأنئ،

.1984
درجات تقليدتهن بين المتوسطة والمنخفضة، مما قد يعزى اليه الأثر الإيجابي لهذا المتغير لإني في تحسين

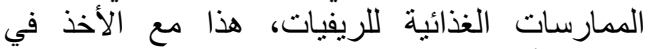
الاعتبار أن مستوى تتفيذ الريفيات للممارسات الغذائية

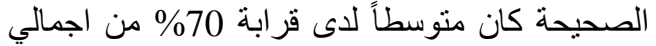

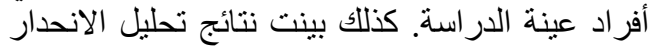

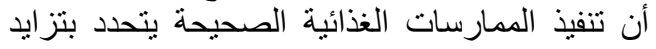

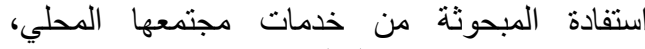

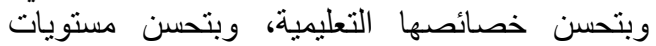

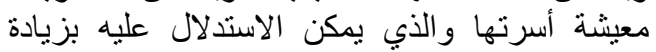

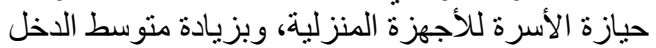
الشهري للأسرة، كما يتحدد تتفيذ الممارسات لإنة الغذائية

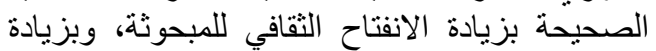
حجم حيازة الأرض الزرة الاعية لأسرتها.

التوصيات والمقترحات

في ضوء النتائج الوصفية والتحليلية فإنه يمكن اقتر اح ما يلي: - - n 1- التأكيد بكل قوة على أهمية جودة خصائص العنصر

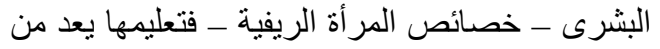

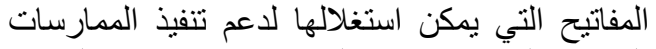

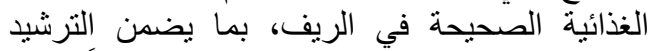

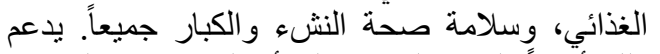

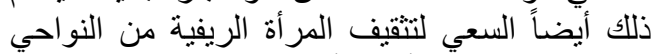
الغذائية، وتو عيتها بأهمية أن تكون ممارساتها الغذائية الغية الغية صحية وسليمة.

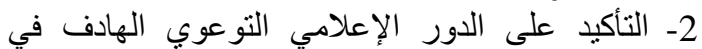

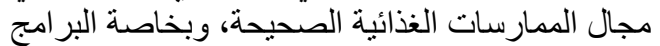

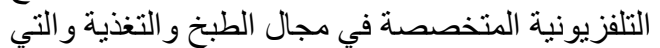

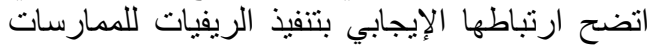
الغذائية الصحيحة. الصنا

المراجع

أبو حسين، إبتهال محمد، سلوك الريفيات نحو العادات

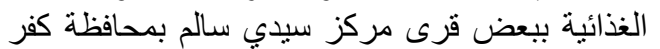

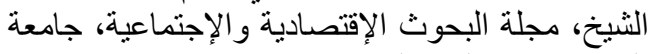
المنصورة، مجلد 5 العدد 7، الإند، 2014.

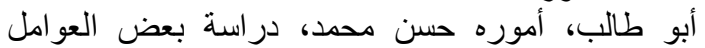

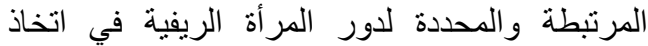

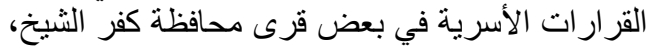
رسالة ماجستير، كلية الزراعة بكفر الإن الثيخ، جامعة طنطا، 2002.

الجارحى، أمان على، الغذاء والتغذية والصحة العامة، التهاء

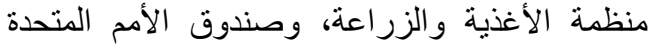

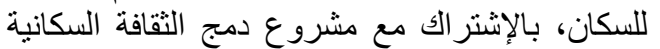
و البيئية فى الإرشاد الزراعى، الإنى الطبعة الثانية، 2000.

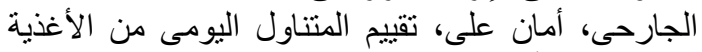

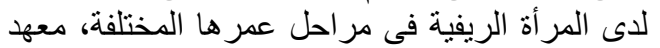

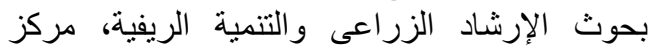


A. M. Alazab, et al.,

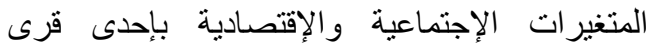

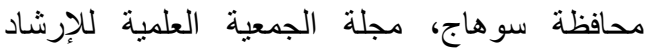

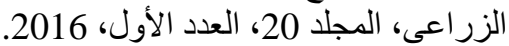

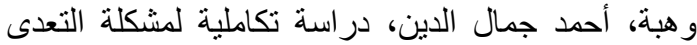

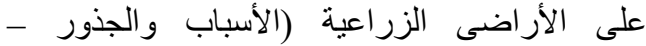

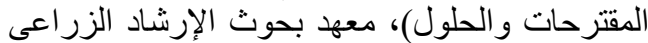

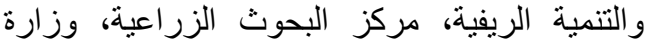

$$
\begin{aligned}
& \text { الزر اعة و إستصلاح الأر اضى، إنى } 2015 .
\end{aligned}
$$

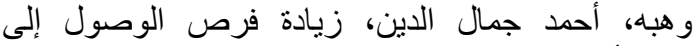

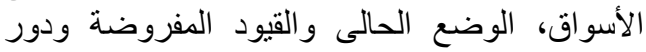

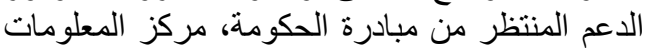

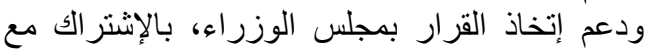

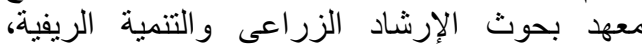

$$
\begin{aligned}
& 2012
\end{aligned}
$$

Krejcie, Robert V. and Daryle W. Morgan (1970). Determining sample size for research activities, Educational and psychological measurments, 30, 607 610

http://extension.sudansgri.net/poots/380826 http://ar.wikipecdia/wiki/
علوي، علوية، الاقتصاد المنزلي والتتمية الريفية، مركز تنمية المجتمع في العالم العربي، سرس اللئي الليان. 1986.

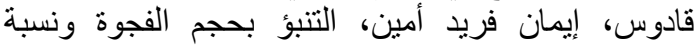

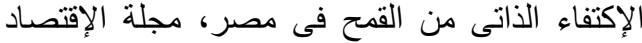

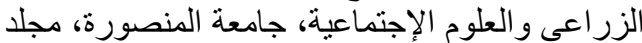
6، العدد 7، يوليو 2015.

مركز المعلومات ودعم اتخاذ القرا بديوان بوليو عان عام محافظة

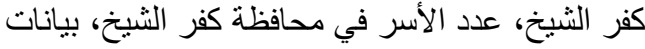

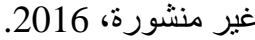

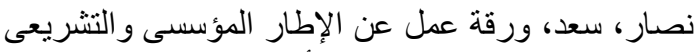

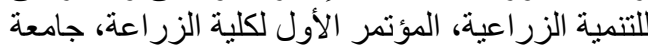

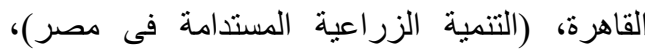
مركز الدراسات الإقتصادية الزراعية الزية، كلية الزراعة الزية، جامعة القاهرة، 10 أكتوبر الإن 2016.

هيكل، أيهاب عبد الخالق محمد، وحسين محمد تهامي،

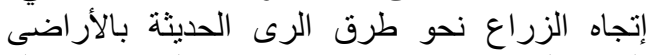
المستصلحة بإحدى قرى منطقة البرى البستان، مجلة الإنة

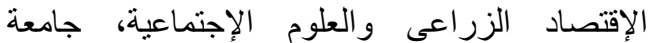

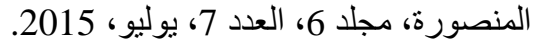

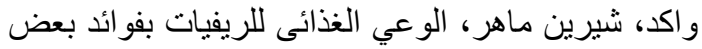

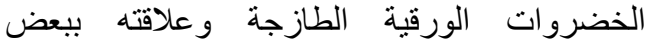

\title{
THE IMPACT OF CURRENT ECONOMIC CONDITIONS ON THE DIETARY PRACTICES OF RURAL FAMILIES AT KAFR EL-SHEIKH GOVERNORATE
}

\author{
A. M. Alazab(1), Mayada A. Awad(2) and Amoura H. Aboutaleb(2) \\ (1) Rural Sociology Dept.، Kafr El-Sheikh University \\ (2) Agric. Extension and Rural Development Research Institute, Agric. Res. Center
}

\begin{abstract}
The study aimed at identify the level of rural women's implementation of correct dietary practices, and to identify the factors correlated with the implementation of these practices in the current economic conditions at Kafr El-Sheikh Governorate. A questionnaire form was designed for this purpose; rural families' dietary practicies as a dependent variable as well as 12 independent variables were included. A random sample of 355 rural wives was selected from two villages at Kafr El-Sheikh district. Frequencies, percentages, $f$ \& $t$ tests, alpha coefficient, simple correlation, stepwise multiple regression (Forward solution) were used to analyze data with SPSS statistical program.

The results of the study were summarized as follows:

1. The descriptive results of the study showed that the characteristics of the majority of rural women in the study sample were somewhat acceptable, whether in terms of average age, education or number of family members, or the use of television programs in the field of cooking, Cultural openness and the degree of traditionalism, or belonging to the community in which they live, and their benefit from the services provided to them within this community.

2. The results of the simple correlation analysis showed that correct dietary practices can be improved by emphasizing the personal characteristics of rural woman and her husband, such as education, benefiting from the cooking programs shown on television, increasing the degree of cultural openness and Increasing agricultural tenure of the respodents and their families, and through increasing the beneficiary's access to the services of their community.
\end{abstract}


3. The results of the regression analysis showed that the implementation of correct dietary practices is determined by increasing the beneficiary's benefit from the services of community, by improving educational characteristics and by improving family's living standards, which can be inferred by increasing the family's possession of household appliances and by increasing the average household monthly income, and By increasing the cultural openness of the respondents and by increasing the acquisition of agricultural land for their families.

Finally, some recommendations were suggested.

Key words: Economic conditions, Diety practices, Rural families. 